\title{
Source Identification and Variation in the Chemical Composition of Rainwater in Southern-Eastern Region of Bangladesh
}

\section{Md. Arif Hossen ( $\sim$ arifhossen0101@gmail.com )}

Chittagong University of Engineering and Technology https://orcid.org/0000-0003-3635-3011

\section{Asiful Hoque}

Chittagong University of Engineering and Technology (CUET)

\section{Md Salauddin}

University College Dublin

\section{Sudip K. Pal}

CUET: Chittagong University of Engineering and Technology

Mohammad G. Muktadir

WaterAid Bangladesh

Hasin Jahan

WaterAid Bangladesh

\section{Research}

Keywords: Chemical composition, Industrial area, Commercial area, Rainwater, Southern-eastern Bangladesh

Posted Date: October 22nd, 2020

DOl: https://doi.org/10.21203/rs.3.rs-92703/v1

License: (c) (1) This work is licensed under a Creative Commons Attribution 4.0 International License. Read Full License 


\section{Abstract}

The present study portrayed a better understanding of the chemical characteristics of rainwater in SouthEastern region of Bangladesh (e.g. Chattogram) as well as to identify the potential sources of different precipitation constituents in the study region that were often unexplored and not well understood. Rainwater $\mathrm{pH}$, major ions, and trace metals were measured in samples collected from five different locations with different land use patterns of Chattogram Metropolitan area (CMA) during the two rainy seasons. The samples were tested following standard protocols. The results of this study exhibit variability in rainwater quality across the sites signifying site-specific influences. The mean concentration of all measured physicochemical parameters, ions and trace metals in rainwater samples were found significantly lower compared to the drinking water quality standard of Bangladesh. In context of ionic constituents, the higher concentrations of nitrate $\left(\mathrm{NO}_{3}{ }^{-}\right)$and sulphate $\left(\mathrm{SO}_{4}{ }^{2-}\right)$ were generally in commercial area. The correlation matrix and principal component analysis (PCA) indicated that $\mathrm{NO}_{3}{ }^{-}$and $\mathrm{SO}_{4}{ }^{2-}$ were from anthropogenic sources, e.g. automobile exhaust, incomplete fuel combustions, and industrial emissions. The average concentration of trace metals in rainwater was followed a decreasing order: $\mathrm{Zn} \otimes \mathrm{Cu} \otimes \mathrm{Fe} \otimes \mathrm{Cr} \otimes \mathrm{Mn} \otimes \mathrm{Pb} \otimes \mathrm{Cd}$. Trace metals concentration, especially copper (Cu) and zinc ( $\mathrm{Zn}$ ) were found maximum in the industrial catchment area. The resulting outcomes of this study could be useful to investigate the influences of industrial, urban, and agricultural emissions that elaborate the physical processes regulating the chemical characteristic of the atmosphere in the investigated area.

\section{Introduction}

Rainwater is considered blessings and is found generally safe and common alternative sources of water around the world that got huge attention of its culture in relation to quality uses in particularly developing countries. Although, rainwater is safe, the chemical compositions at the point of collection is seen altered influenced by local environment and atmospheric condition; hence, different places might see different elemental concentrations in place that is often key to define suitability of uses. Rainwater chemistry is formed through a dynamic interaction between the atmospheric (e.g. cloud) dynamics and the microphysical actions in together with a sequence of 'rainout and washout atmospheric chemical reactions' [1-4]. Rainwater chemistry signifies the chemical characteristics of the atmosphere through which it falls, helps to understand and investigate the soluble elements exists in rainwater as noted by Wang and Han [5]. Rainwater compositions provide insight into the relative contributions of different atmospheric pollutants, and their regional dispersion [6-7]. Additionally, it also helps to investigate the site-specific characteristics, such as influences of emissions from industrial, urban, and agricultural sectors, and the biogeochemical factors that elaborate the physical processes regulating the chemical characteristic of the atmosphere in regional areas and natural biogeochemical cycle [8-9].

Chattogram, a commercial capital and one of the largest port cities in Bangladesh is situated in the eastern coastal zone of Bangladesh [10]. The city is a home of nearly 4.5 million people and the sources of water are in mixed modes of surface and groundwater. However, ground water near the coastal belt see 
substantially high salinity in dry period due to little or no rainfall along with arsenic in few cases in shallow tube wells at household scale [11-12]. Therefore, people mostly depend on the water supplied by Chattogram Water Supply and Sewerage Authority (CWASA) both for domestic and drinking purposes that are intermittent and fall short in coverage fulfilling around $69 \%$ demand for city dwellers. In absence of wastewater treatment facilities and poor solid waste management system, the river water quality near city area is found unsuitable, hence, CWASA has to go further upstream covering the great distance for searching comparatively less polluted surface water suitable for treatment for its connected [13-14]. Taking poor quality surface water and groundwater with high salinity and arsenic in consideration, the rainwater culture is an only option left and is seen as blessing due to the volume of precipitation received during monsoon in Bangladesh.

While the potential rainwater harvesting methods and opportunities across Bangladesh are increasingly being studied [15-17], the chemical characteristics of rainwater and the variation of relative contributions of different atmospheric pollutants with respect to different land uses remain generally unexplored considering its merit for suitability of uses. There have been surprisingly very few studies devoted to investigating the chemical composition of rainwater around the globe. In Bangladesh particularly in Southern-Eastern region of the country e.g. Chattogram, no such study is found at present. These knowledge gaps are contributed to this study, which describes the results of a comprehensive experimental investigation on rainwater chemistry in Chattogram region across various social and economic zones of the city, e.g. industrial, residential, and urban area. The main purpose of this study to obtain a better understanding of the chemical composition of rainwater across varying geographical locations of Chattogram as well as to identify the potential sources of different precipitation constituents in the study region.

\section{Materials And Methods}

The rainwater chemistry was identified by comprehensive field and laboratory tests on various water quality parameters, e.g. pH, turbidity, alkalinity, hardness, major ions, trace metals, etc. The resulting chemical composition of rainwater obtained in this study are then compared with the existing standards of water quality parameters that are applicable to the study region.

\subsection{Study Area}

The city Chattogram is a noteworthy coastal city and commercial hub located in the south-eastern sides of Bangladesh. Chattogram Metropolitan area (CMA) is four times greater than the Chattogram City Corporation (CCC) area, situated as shown in Fig. $1\left(22^{\circ} 6^{\prime} 41^{\prime \prime} \mathrm{N}-22^{\circ} 33^{\prime} 38^{\prime \prime} \mathrm{N}, 90^{\circ} 41^{\prime} \mathrm{E}-92^{\circ} 2^{\prime} \mathrm{E}\right)$. The city is bounded by the Bay of Bengal on the west, by Halda River on the north-east and, by Karnaphuli River on the south-east. The busiest seaport of Bangladesh is located at the estuary of the Karnafuli River [18]. Due to this port facility, the city is business friendly that's why more than hundreds of oldest and largest industries of Bangladesh established here [19]. The CMA is one of the critical coastal regions of the 
country with around 4.5 million inhabitants (density $6000 / \mathrm{km}^{2}$ ) with a growth rate of $2.06 \%$ per annum [20].

Geographically, the core city area is plain land and low height hillocks mainly towards the north with a peak elevation of $351 \mathrm{~m}$ in Sitakunda [21]. The tropical monsoon climate mostly dominates the weather characteristics of the city. According to the available data from Chattogram station of Bangladesh Meteorological Department (BMD), $2400 \mathrm{~mm}$ and $3000 \mathrm{~mm}$ annual rainfall occurs in Chattogram region of which $80 \%$ of total occurs between May and September (Fig. 2). In which, the mean annual relative humidity is $73.7 \%$ and mean monthly relative humidity varies from $58 \%$ in January to $86 \%$ in August [22]. During dry weather usually mild cold wind blows from the north to the south of the country with very little precipitation. The average maximum and minimum air temperature are $32.3^{\circ} \mathrm{C}$ and $13^{\circ} \mathrm{C}$, in summer and winter, respectively [22]. In this study, five locations are selected addressing different land uses for collecting rainwater samples in which three of them are in the city centre (Fig. 1), while the remaining two sites are outsides of city centre, one of which is an industrial area named Kumira and another one is a sub-urban residential area named Pahartali. Generally, in a field, there exist residential, commercial and industrial characteristics, that's why in this study, all of the city based on their land use for specific purposes are selected, e.g. Figure 1. Rainwater parameters of GEC and Agrabad locations particularly belong to commercial land use might have been influenced by the road traffic environment as of high traffic volume.

Meanwhile, the highest traffic-induced noise pollution was recorded in the commercial areas (e.g. GEC intersection and Agrabad circle in Fig. 1.) [18,23]. The growing concern for city dwellers is air pollution, mostly caused by automobile emission as the number of vehicles are increasing day by day, in 2010 registered vehicles was 84,391 . Still, besides that, there are several thousands of non-registered vehicles [24]. Suspended Particulate Matter (SPM), sulphur dioxide $\left(\mathrm{SO}_{2}\right)$ and nitrogen oxides (NOx) are the three major components of air pollution in Chattogram city with SPM being the most concentrated [18, 25]. Pahartali site is mainly residential in nature where most of the Bangladesh Railway residence is situated. Kumira is an industrial area located in the north of the CMA one side of which is the Bay of Bengal and other side is hills. Besides, various cement, glass and steel manufacturing industries, South Asian one of the famous ships breaking industry situated here. The soil, water and also air around the ship breaking industries is greatly polluted by toxic substances [26-28]. On the other hand, Chittagong University of Engineering \& Technology (CUET) is situated in Raozan Upazila very different from other sites and can be considered pristine site with little or no significant pollution, which is not part of CMA. The area is suburban with relatively clean environment where agricultural land use persists on top of academic activities.

\subsection{Sample Collection}

The samples of rainwater were taken on an event basis. Total ninety-five wet-only rainwater samples were collected from two rainy seasons (June 2018 to October 2018 and June 2019 to October 2019).

Rainwater collector shown in Fig. 3 was placed on the roof of building at each of the rainwater sampling sites described above with varying heights ranged 10 to $20 \mathrm{~m}$. First flush tank was incorporated to 
sperate the rainwater after first flush by using ballcock. In this study, the water from rainwater tank was used to analyse. In rainwater tank, there also a ballcock used to prevent passing of remaining rainwater stayed in catchment after filling up rainwater tank. It's because, during the time between rainfall and collection there is a chance of contamination by birds and insects since the catchment was open whereas rainwater tank was closed. In this study, first flush water was not considered for testing since in most of the study it was suggested to let the first flush water go as it is considered polluted [29-31]. Between two rain events, the rainwater tank was cleaned manually while the dry deposition of pollutants primarily influenced by atmospheric fall out cannot be avoided. Immediately after each rainfall events the rainwater samples were collected by using $500 \mathrm{ml}$ polypropylene bottle. Before collecting, the bottles were washed by using distilled water to avoid cross contamination.

\subsection{Sample Collection}

Table 1 summarizes the analytical parameters and methods used for determining rainwater quality. Potential of hydrogen $(\mathrm{pH})$, electrical conductivity (EC) and TDS were measured at in situ by using Smart Digital $\mathrm{pH}$ meter and HQ40D Multi-meter. The $\mathrm{pH}$ meter has been calibrated using 4.0, 7.0, and $10.0 \mathrm{pH}$ buffer solutions. All the samples were stored at $4{ }^{\circ} \mathrm{C}$ until analysis. Prior to analysis, samples were filtered by using No. 1 Whatman ${ }^{\circledR}$ filter paper to remove the insoluble particles. The standard analytical protocol following quality control and quality assurance has been maintained for the experiments conducted in the Environmental Engineering Laboratory at CUET.

Table 1

Analytical methods used for the determination of the rainwater quality

\begin{tabular}{|c|c|}
\hline Parameters & Analytical Method \\
\hline $\mathrm{pH}$ & Smart Digital pH Tester \\
\hline Electrical Conductivity (EC) & HQ40D Multi Meter \\
\hline Total dissolved solids (TDS) & HQ40D Multi Meter \\
\hline Turbidity & 2100Q Portable Turbidimeter \\
\hline Alkalinity $\left(\right.$ as $\left.\mathrm{CaCO}_{3}\right)$ & $\begin{array}{l}\text { Titration with } 0.02 \mathrm{~N} \mathrm{H}_{2} \mathrm{SO}_{4} \text { using } \\
\text { methyl orange }\end{array}$ \\
\hline Hardness (as $\mathrm{CaCO} 3$ ) & $\begin{array}{l}\text { Titration with } 0.02 \mathrm{~N} \mathrm{NaOH} \text { using } \\
0.1 \text { EDTA }\end{array}$ \\
\hline $\begin{array}{l}\text { Ions [Nitrate }\left(\mathrm{NO}_{3}{ }^{-}\right) \text {, Sulphate }\left(\mathrm{SO}_{4}{ }^{2-}\right) \text {, Phosphate }\left(\mathrm{PO}_{4}{ }^{3-}\right) \text { and } \\
\text { Ammonium }\left(\mathrm{NH}_{4}{ }^{+}\right) \text {] }\end{array}$ & $\begin{array}{l}\text { DR1900 Portable } \\
\text { Spectrophotometer }\end{array}$ \\
\hline Trace Metals (Fe, Cu, Zn, Pb, Mn, Cr \& Cd) & $\begin{array}{l}\text { AA-6200 Atomic Absorption } \\
\text { Spectrophotometer }\end{array}$ \\
\hline
\end{tabular}




\section{Results And Discussion}

\subsection{Physicochemical analysis}

All the physicochemical parameters investigated in this study were found well below than the Bangladesh standard in all selected land use locations. The descriptive statistics of physicochemical parameters tabulated in Table 2, while for ease of understanding the average concentrations of the parameters are kept in bar chart plot in. The average $\mathrm{pH}$ values ranged from 6.07 to 6.75 in all tested samples which is in slightly acidic range. The EC and TDS were recorded higher in industrial area, indicating presence of more ions dissolved in the rainwater at that location (Fig. 4). Turbidity were found in similar range in all locations slightly higher in commercial area due to the presence of high quantity of dust particles in air of that region, although turbidity is not inevitably a health threat, it may possibly create a health hazard if the suspended particles have adsorbed toxic organic or inorganic compounds [30]. Average concentration of alkalinity and hardness were found somewhat higher in commercial area.

Table 2 Descriptive statistics of physicochemical parameters of rainwater

\begin{tabular}{|c|c|c|c|c|c|c|c|c|c|c|c|c|c|c|c|c|c|}
\hline \multirow[t]{2}{*}{ Parameter } & \multicolumn{4}{|c|}{ Industrial Area } & \multicolumn{4}{|c|}{ Commercial Area } & \multicolumn{4}{|c|}{ Residential Area } & \multicolumn{4}{|c|}{ Sub'urban Area } & \multirow{2}{*}{$\begin{array}{c}\text { Bangladesh } \\
\text { Standard, } \\
\text { ECR'97 }\end{array}$} \\
\hline & Min & $\operatorname{Max}$ & Asg & SD & Min & $\operatorname{Max}$ & Avg & SD & Min & $\operatorname{Max}$ & Avg & SD & Min & $\operatorname{Max}$ & Avg & SD & \\
\hline $\mathrm{pH}$ & 4.68 & 7.82 & 6.73 & 0.68 & 6 & 7.24 & 6.77 & 0.39 & 5.09 & 6.72 & 6.10 & 0.38 & 5.36 & 8.66 & 6.75 & 0.76 & $6.5 \cdot 8.6$ \\
\hline $\mathrm{TD} s(\mathrm{mg} / \mathrm{l})$ & 5.59 & 620 & 81.77 & 121.21 & 7.34 & 227 & 54.24 & 60.42 & 10.20 & 131.00 & 36.51 & 39.86 & 7.62 & 45.40 & 30.99 & 9.95 & 1000 \\
\hline $\begin{array}{l}\mathrm{EC}(\mu 8 / \mathrm{cm}) \\
\text { Alkalinity }\end{array}$ & 7.85 & 873 & 128.8 & 172.61 & 10.34 & 383 & 77.69 & 89.09 & 14.46 & 184.00 & 56.60 & 49.61 & 18.30 & 107.6 & 55.14 & 16.0 & $\ldots$. \\
\hline$(\mathrm{mg} / \mathrm{l})$ & 7 & 20 & 12.76 & 3.23 & 5 & 70 & 26.16 & 18.48 & 6.00 & 15.00 & 9.11 & 2.32 & 20.00 & 35.00 & 24.79 & 4.62 & $\ldots .$. \\
\hline $\begin{array}{l}\text { Hardness } \\
(\mathrm{mg} / \mathrm{l})\end{array}$ & 30 & 170 & 65.00 & 25.41 & 25 & 215 & 77.81 & 43.81 & 35.00 & 80.00 & 52.50 & 11.15 & 10.00 & 90.00 & 58.54 & 16.4 & $200 \cdot 500$ \\
\hline $\begin{array}{l}\text { Turbidity } \\
\text { (NTU) }\end{array}$ & 0.4 & 11.31 & 2.75 & 2.40 & 0.51 & 8.51 & 3.66 & 2.21 & 0.67 & 1.81 & 1.22 & 0.31 & 0.41 & 2.93 & 1.47 & 0.62 & 10 \\
\hline
\end{tabular}

\section{2. $\mathrm{pH}$ value and ionic composition}

Natural rainwater is normally considered to be weakly acidic with a $\mathrm{pH}$ value of 5.6 when the atmosphere is free from pollution [32-33]. Statistical variation of $\mathrm{pH}$ at different land use locations is shown in Fig. 5. The maximum $\mathrm{pH}$ (8.66) was recorded in residential (sub-urban) area whereas minimum value (4.68) was found in industrial area. Considering the variability and anthropogenic input at different sites, the residential catchment in Pahartali relatively clean with no surrounding input sources, exhibit the wide range of $\mathrm{pH}$ compared to other sites with urban, commercial and industrial surroundings. The relatively smaller variation in other rial catchment in comparison to sub urban catchment illustrate site-specific characteristics influenced by the anthropogenic input (road traffic and industrial emission) during precipitation followed by dry deposition between rain events. The similar variations are also seen in studies elsewhere [34-35].

Descriptive statistics for major ions in rainwater of different locations are given in Table 3. For the all four sampling locations, $\mathrm{SO}_{4}{ }^{2-}$ was the highest dominant major ion, with an average concentration of 192.5, 
274.7, 90.3 and $89.6 \mu \mathrm{eq} / \mathrm{l}$, for industrial, commercial, residential (urban) and residential (sub-urban) area, respectively. The maximum concentration of $\mathrm{NO}_{3}{ }^{-}$and $\mathrm{SO}_{4}{ }^{2-}$ were found in commercial area where rainwater quality might be influenced by vehicular emission than other locations. Most of the time vehicles are in traffic congestion in that location which increases vehicular emission [24]. Contribution of $\mathrm{NO}_{3}{ }^{-}$and $\mathrm{SO}_{4}{ }^{2-}$ in commercial area are $36 \%$ and $41 \%$, respectively, among all locations as depict in Fig. 6. The percentages of $\mathrm{NH}_{4}{ }^{+}$in residential (sub-urban) area was recorded maximum (38\%) around where agricultural activities are seen to be performed, whereas the highest mean concentration $(7.2$ $\mu e q / \mathrm{l})$ of $\mathrm{PO}_{4}{ }^{3-}$ was found in industrial area. The presence of $\mathrm{PO}_{4}{ }^{3-}$ in rainwater may be a sign of bird or insect faces contamination as noted by Huston et al. [36].

Table 3 Statistical representation of different ions and trace metals in rainwater samples

\begin{tabular}{|c|c|c|c|c|c|c|c|c|c|c|c|c|}
\hline Parameter & & $\mathrm{NO}_{3}$ & $\mathrm{SO}_{4}$ & $\mathrm{PO}_{4}$ & $\mathrm{NH}_{4}$ & $\mathrm{Fe}$ & $\mathrm{Cu}$ & $\mathrm{Zn}$ & $\mathrm{Pb}$ & $\mathrm{Mn}$ & $\mathrm{Cr}$ & $\mathrm{Cd}$ \\
\hline \multirow{4}{*}{ Industrial Area } & Min & BDL & BDL & 0.6 & BDL & BDL & BDL & 110.0 & BDL & 1.0 & 2.0 & BDL \\
\hline & $\operatorname{Max}$ & 87.9 & 812.5 & 20.5 & 24.1 & 440.0 & 620.0 & 630.0 & BDL & 25.0 & 94.0 & BDL \\
\hline & Avg. & 25.5 & 192.5 & 7.2 & 3.9 & 47.2 & 82.8 & 240.0 & BDL & 8.4 & 29.2 & BDL \\
\hline & $\mathrm{CV}(\%)$ & 75.2 & 112.7 & 77.9 & 125.1 & 179.2 & 148.8 & 52.5 & & 73.6 & 64.5 & \\
\hline \multirow{4}{*}{$\begin{array}{l}\text { Commercial } \\
\text { Area }\end{array}$} & Min & 7.1 & $\mathrm{BDL}$ & 1.6 & 0.8 & BDL & BDL & 8.0 & BDL & 1.0 & 20 & BDL \\
\hline & $\operatorname{Max}$ & 164.4 & 1062.5 & 10.1 & 3.2 & 100.0 & 60.0 & 320.0 & 42.0 & 38.0 & 72.0 & BDL \\
\hline & Avg. & 30.5 & 274.7 & 6.0 & 1.9 & 36.7 & 20.9 & 175.6 & 8.3 & 14.3 & 32.4 & BDL \\
\hline & $\mathrm{CV}(\%)$ & 107.4 & 106.3 & 71.2 & 64.4 & 57.0 & 63.5 & 42.1 & 194.1 & 72.3 & 54.1 & \\
\hline \multirow{4}{*}{ Residential Area } & Min & BDL & BDL & 0.6 & 0.8 & 10.0 & BDL & 80.0 & BDL & 1.0 & 4.0 & BDL \\
\hline & $\operatorname{Max}$ & 51.9 & 270.8 & 12.6 & 4.0 & 40.0 & 480.0 & 530.0 & BDL & 15.0 & 52.0 & BDL \\
\hline & Avg. & 16.4 & 90.3 & 3.9 & 2.0 & 23.3 & 42.9 & 219.3 & BDL & 5.5 & 18.8 & BDL \\
\hline & $\mathrm{CV}(\%)$ & 73.4 & 94.7 & 99.6 & 52.8 & 29.4 & 263.7 & 54.6 & & 76.5 & 70.6 & \\
\hline \multirow{4}{*}{ Sub-Urban Area } & Min & BDL & BDL & 0.3 & 0.8 & 20.0 & 10.0 & 60.0 & BDL & 1.0 & 20 & BDL \\
\hline & $\operatorname{Max}$ & 50.0 & 333.3 & 25.9 & 26.6 & 320.0 & 310.0 & 570.0 & BDL & 12.0 & 13.0 & BDL \\
\hline & Avg. & 15.2 & 89.6 & 4.0 & 5.7 & 69.6 & 53.3 & 192.1 & BDL & 6.1 & 6.5 & BDL \\
\hline & $\mathrm{CV}(\%)$ & 72.5 & 113.0 & 141.1 & 139.1 & 91.5 & 111.1 & 57.7 & & 46.5 & 46.3 & \\
\hline \multicolumn{2}{|c|}{ Bangladesh Standard, ECR97 } & 10,000 & $4,00,000$ & 6,000 & $\cdots$ & $\begin{array}{l}300- \\
1.000\end{array}$ & 1,000 & 5,000 & 50 & 100 & 50 & 5 \\
\hline
\end{tabular}

*.* Unit of all ions are in $\mu \mathrm{sg} / 1$ and trace metals in $\mu \mathrm{g} /$.

*.* BDL stands for below detection limit.

\subsection{Trace Metals}

A statistical summary of trace metal concentrations in rainwater samples of different selected sites is presented in Table 3. It is observed that the average concentrations of all selected trace metals are well below than the Bangladesh drinking water standard. Elevated concentration of $\mathrm{Zn}$ was found in all analyzed samples, although the limiting value of $\mathrm{Zn}$ also much higher than other metals. Comparatively, the higher concentration of $\mathrm{Zn}$ and $\mathrm{Cu}$ was found in industrial area. The mean concentration of copper (Cu) in industrial area was $74.7 \%, 48.2 \%$ and $35.6 \%$ greater than the commercial, residential (urban) and residential (sub-urban) area, respectively. Industrial areas are usually influenced by metal intensive activities, and the widespread use of metals, such as $\mathrm{Fe}, \mathrm{Cu}$ and $\mathrm{Zn}$ in industries, are reflected in higher concentrations in rainwater of these metals [37-38]. The average concentration of Fe was recorded $47.2 \mu \mathrm{g} / \mathrm{l}, 36.7 \mu \mathrm{g} / \mathrm{l}, 23.3 \mu \mathrm{g} / \mathrm{l}$ and $69.6 \mu \mathrm{g} / \mathrm{l}$ in industrial, commercial, residential (urban) and residential (sub-urban) area, respectively. $\mathrm{Pb}$ was only found in the rainwater of commercial area. Highest average concentration $(32.3 \mu \mathrm{g} / \mathrm{l})$ of $\mathrm{Cr}$ found in commercial area while lowest average concentration $(6.5 \mu \mathrm{g} / \mathrm{l})$ recorded in residential (sub-urban) area. Mn was found in elevated concentration in commercial area while $\mathrm{Cd}$ was found below detection limit in all sampling sites. Atmospheric deposition is one of the significant pathways of trace metals presence in urban rainwater and is mostly impacted by site-specific emissions [37]. As vehicular emissions in the commercial area are ample than those of residential area, 
this pathway (atmospheric deposition) could contribute to the elevated concentration of trace metals in the commercial site [39].

It is observed that the average concentration of trace metals in all analyzed samples followed a decreasing order of $\mathrm{Zn} \otimes \mathrm{Cu} \otimes \mathrm{Fe} \otimes \mathrm{Cr} \otimes \mathrm{Mn} \otimes \mathrm{Pb} \otimes \mathrm{Cd}$. The percentages of total concentration for selected trace metals in different land use locations are shown in Fig. 7. Cu and Zn, together accounted $80 \%$ of total concentration in industrial area while $67 \%$ for commercial area, $84 \%$ for residential (urban) area and $74 \%$ for residential (sub-urban) area.

\subsection{Worldwide comparison}

The precipitation analysis of this study is compared with the data from other areas of Bangladesh as well as worldwide. In Table 4, the physicochemical characteristics of rainwater measured for this study area have been compared with those observed worldwide in other studies. The $\mathrm{pH}$ of rainwater samples was in the range from 4.68 to 7.82 , with a mean value of $6.63 \pm 0.62$, i.e. is in the acidic range, reveals the similar characteristics as reported in other parts of the world. The concentrations of TDS and EC were found lower within this work when compared to those observed in other areas, but smaller than Korea. The measured values of alkalinity and hardness for the tested area were higher than those reported in other parts of the world, see Table 4. The concentration of turbidity was much lower than those observed in worldwide but slightly higher than those in another city of Bangladesh, i.e. Sylhet. In general, it is seen that the differences and variability among different sites within city, country, region and globe are reflected in the results, as expected, that signify the in-depth investigation prior to rainwater harvesting potential at sites. The mean concentrations of ions and trace metals in the study area for all samples are presented in Table 5 in conjunction with those reported for other regions around the world. Overall, the concentration of nitrate $\left(\mathrm{NO}_{3}{ }^{-}\right)$was found much lower in the investigated area in comparison to those observed in other sampling sites in the world, as shown in Table 5. The sulphate concentration (161.8 $\mu e q / I)$ was observed to be slightly high, when compared with those reported in the literature for similar sampling locations around the world, except for the Taiwan in the republic of China $(238.2 \mu \mathrm{eq} / \mathrm{l})$. The observed values of $\mathrm{NH}_{4}{ }^{+}$were much lower in precipitation reported here compared to those observed in the sampling sites around the world. The $\mathrm{PO}_{4}{ }^{3-}$ concentration was slightly lower than that of India. 
Table 4

Comparison of physicochemical characteristics of rainwater between this study and worldwide other studies

\begin{tabular}{|c|c|c|c|c|c|}
\hline Parameter & $\begin{array}{l}\text { This } \\
\text { study }\end{array}$ & $\begin{array}{l}\text { Sylhet, } \\
\text { Bangladesh }\end{array}$ & $\begin{array}{l}\text { Haryana, } \\
\text { India }{ }^{(b)}\end{array}$ & $\begin{array}{l}\text { Loess Plateau, } \\
\text { China(c) }\end{array}$ & $\begin{array}{l}\text { Jeju, } \\
\text { Korea }\end{array}$ \\
\hline $\mathrm{pH}$ & $\begin{array}{l}6.63 \pm \\
0.62\end{array}$ & 7.6 & 6.85 & 7.48 & 5.2 \\
\hline TDS & $\begin{array}{l}52.3 \pm \\
73.2\end{array}$ & 80 & 105 & 61.3 & 23.4 \\
\hline EC & $\begin{array}{l}81.3 \pm \\
105.6\end{array}$ & $\ldots \ldots$ & 195 & 94.28 & 36 \\
\hline Alkalinity & $\begin{array}{l}19.3 \pm \\
13.01\end{array}$ & 13.2 & $\ldots \ldots$ & $\ldots \ldots$ & $\ldots \ldots$ \\
\hline Hardness & $\begin{array}{l}65.3 \pm \\
30.7\end{array}$ & 23 & 32 & $\ldots \ldots$ & $\ldots \ldots$ \\
\hline Turbidity & $2.5 \pm 2.02$ & 0.56 & 11 & 4.5 & 4.8 \\
\hline \multicolumn{6}{|c|}{ 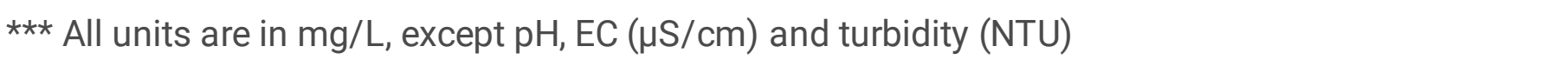 } \\
\hline
\end{tabular}


Table 5

Comparison of ions $(\mu \mathrm{eq} / \mathrm{l})$ and trace metals $(\mu \mathrm{g} / \mathrm{l})$ in rainwater between Chattogram, Bangladesh and other locations

\begin{tabular}{|c|c|c|c|c|c|c|}
\hline Parameter & $\begin{array}{l}\text { This } \\
\text { study }\end{array}$ & $\begin{array}{l}\text { Ghore El-Safi, } \\
\text { Jordan }^{(a)}\end{array}$ & $\begin{array}{l}\text { Mexico City, } \\
\text { Mexico }\end{array}$ & $\begin{array}{l}\text { Lucknow, } \\
\text { India(c) }\end{array}$ & $\begin{array}{l}\text { Tai'an, } \\
\text { China(d) }\end{array}$ & $\begin{array}{l}\text { Suburb, } \\
\text { Japan(e) }\end{array}$ \\
\hline $\mathrm{NO}_{3}^{-}$ & $\begin{array}{l}21.9 \pm \\
22.9\end{array}$ & 67.3 & 42.6 & 58.5 & 64.3 & 9.8 \\
\hline $\mathrm{SO}_{4}{ }^{2-}$ & $\begin{array}{l}161.8 \\
\pm 220\end{array}$ & 112.4 & 61.9 & 104.2 & 238.2 & 24.4 \\
\hline $\mathrm{PO}_{4}^{3-}$ & $\begin{array}{l}5.3 \pm \\
5.2\end{array}$ & $\ldots \ldots$ & $\ldots \ldots$ & 6.9 & $\ldots \ldots$ & $\ldots \ldots$ \\
\hline $\mathrm{NH}_{4}^{+}$ & $\begin{array}{l}3.4 \pm \\
5.7\end{array}$ & 75.4 & 92.4 & 42.4 & 167.1 & 11.1 \\
\hline $\mathrm{Fe}$ & $\begin{array}{l}45.1 \pm \\
56.2\end{array}$ & 430 & $\ldots \ldots$ & 69.2 & 41.2 & 7.5 \\
\hline $\mathrm{Cu}$ & $\begin{array}{l}48.5 \pm \\
85.6\end{array}$ & 73 & $\ldots \ldots$ & 0.37 & 7.9 & 2.5 \\
\hline$Z n$ & $\begin{array}{l}203.7 \\
\pm 108\end{array}$ & 210 & $\ldots \ldots$ & 17.6 & 85.2 & 18 \\
\hline $\mathrm{Pb}$ & $\begin{array}{l}5.1 \pm \\
12.9\end{array}$ & 66 & 58.7 & 1.2 & 5.9 & $\ldots \ldots$ \\
\hline $\mathrm{Mn}$ & $\begin{array}{l}9.2 \pm \\
7.7\end{array}$ & $\ldots \ldots$ & 79.7 & 6.9 & 14.2 & 11 \\
\hline $\mathrm{Cr}$ & $\begin{array}{l}22.7 \pm \\
18.0\end{array}$ & 3.1 & 46.2 & 9.5 & 0.06 & $\ldots \ldots$ \\
\hline $\mathrm{Cd}$ & BDL & 52 & 80.5 & BDL & 0.61 & $\ldots \ldots$ \\
\hline
\end{tabular}

Table 6

Enrichment factors of trace metals at different locations

\begin{tabular}{|llllll|}
\hline Locations & $\mathrm{Cu}$ & $\mathrm{Zn}$ & $\mathrm{Pb}$ & $\mathrm{Mn}$ & $\mathrm{Cr}$ \\
\hline Industrial area & 2443.4 & 3098.5 & $\ldots \ldots .$. & 7.3 & 262.6 \\
\hline Commercial area & 795.4 & 2918.9 & 516.2 & 16.1 & 374.2 \\
\hline Residential (urban) & 1794.3 & 4010.5 & $\ldots \ldots .$. & 6.8 & 239.4 \\
\hline Residential (sub-urban) & 1067.6 & 1682.2 & $\ldots \ldots .$. & 3.6 & 39.6 \\
\hline
\end{tabular}

The trace metal concentrations reported here ( $\mathrm{Fe}, \mathrm{Cu}, \mathrm{Zn}, \mathrm{Pb}, \mathrm{Mn}, \mathrm{Cr}$, and $\mathrm{Cd}$ ) were overall somewhat higher than those reported worldwide, see Table 5. It is evident from Table 5 that the concentration of $\mathrm{Zn}$ 
$(203.7 \mu \mathrm{g} / \mathrm{l})$ was found to be one of the highest concentrations of trace metals in the study area, which was also considerably higher than those found in Mexico, India, and Japan, except for the Jordan $(210 \mu \mathrm{g} / \mathrm{l})$. The Fe concentration $(45.1 \mu \mathrm{g} / \mathrm{l})$ was much lower in the investigated area when compared with those reported in Jordan, and India, but higher than China and Korea. The concentration of $\mathrm{Cu}$ $(48.5 \mathrm{\mu g} / \mathrm{l})$ within this study was moderately higher than that reported in Mexico, India, and Japan, but lower than that of Jordan. The mean $\mathrm{Pb}$ value was found close to those observed in other sampling sites in Asia, i.e. India and China, but much smaller than those in Jordan and Mexico. Overall, the concentrations of $\mathrm{Mn}$ and $\mathrm{Cd}$ were reported lower in this work compared to the data worldwide. The $\mathrm{Cr}$ value was found somewhat higher than those reported around the world, except for Mexico.

\subsection{Enrichment factor of trace metals}

Enrichment factors (EFs) are generally practiced to find the source of ions and metals in rainwater [4748]. Crustal enrichment factor ( $\left(\mathrm{F}_{\text {crust }}\right)$ was used in this study to identify the non-crustal or anthropogenic sources of trace metals in rainwater. $\mathrm{EF}_{\text {crust }}$ was calculated by using the following equation i.e. Eq. 1 [49]:

$$
E F_{\text {crust }}=\frac{\left(\frac{X}{R E F}\right)_{\text {rain }}}{\left(\frac{X}{R E F}\right)_{\text {crust }}}
$$

Where, in Eq. (1) $[X]_{\text {rain }}$ is the concentrations of specific metals in rainwater and $[R E F]_{\text {rain }}$ is the concentrations of reference metals in rainwater. Similarly, $[\mathrm{X}]_{\text {crust }}$ and $[\mathrm{REF}]_{\text {crust }}$ are the concentrations in crustal material. In this study iron ( $\mathrm{Fe}$ ) is taken as a reference metals because "iron is the most abundant element, by mass, in the earth, constituting about $80 \%$ of the inner and outer cores of earth" [50]. The enrichment factors were calculated by using the composition of continental crustal elements from Rudnick and Gao [51]. In general, an element with an enrichment factor (EF) value significantly greater or drastically lower than 1 is assumed to be enriched or diluted relative to the reference source [52-53]. Average enrichment factors for selected trace metals in rainwater are presented in Table 6 for all locations. EF of different metals were found more or less like this study by Uygur et al. [54] and Báez et al. [43]; while they have used $\mathrm{Al}$ and $\mathrm{Mg}$ as a reference metal. Every metal shows too much higher enrichment factor (especially $\mathrm{Cu}$ and $\mathrm{Zn}$ ) which suggesting the presence of anthropogenic sources. Enrichment of $\mathrm{Zn}$ in rainwater like this study has been reported by others, also [44, 46]. Mn had much smaller EF values compared to the remainder of the metals, that were also observed greater than one, exhibiting 16 at commercial area, 7.3 at industrial area, 6.8 at residential (urban) area and 3.6 at residential (sub-urban) area, respectively.

\subsection{Correlation matrix}


The correlation matrix is a helpful way to characterize the relationship among the species present in rainwater samples. To investigate the relationship within the rainwater quality parameters, Spearman's rank correlation analysis was done and shown in Fig. 8. The electrical conductivity (EC) is a comprehensive indicator of the total dissolved solids in precipitation [55], offering a robust correlation with TDS. No apparent correlations between $\mathrm{pH}$ value and $\mathrm{NO}_{3}{ }^{-}$indicated that $\mathrm{NO}_{3}{ }^{-}$present as salt $\left(\mathrm{NH}_{4} \mathrm{NO}_{3}\right)$, since somewhat good relation present in $\mathrm{NH}_{4}{ }^{+}$and $\mathrm{NO}_{3}{ }^{-}(-0.42)$ [32]. Nitrates may potentially transfer from the air to various water sources (e.g. ground, lakes, and surface water) using rainwater [5657]. $\mathrm{SO}_{4}{ }^{2-}$ mostly dominates $\mathrm{pH}$ in this study and $\mathrm{PO}_{4}{ }^{3-}$ rather than $\mathrm{SO}_{4}{ }^{2-}$ and $\mathrm{NO}_{3}{ }^{-}$since somewhat significant correlation exists among $\mathrm{pH}, \mathrm{SO}_{4}{ }^{2-}$ and $\mathrm{PO}_{4}{ }^{3-}(-0.57) . \mathrm{NO}_{3}{ }^{-}$and $\mathrm{SO}_{4}{ }^{2-}$ showed good correlation (0.48) in samples whereas $\mathrm{PO}_{4}{ }^{3-}$ and $\mathrm{NO}_{3}{ }^{-}(0.74)$ and $\mathrm{PO}_{4}{ }^{3-}$ and $\mathrm{SO}_{4}{ }^{2-}(0.68)$ exhibit strong associations. In relation to source apportion, it has been found that the combustion processes with the use of fuel oil with a sulphur content that occur in industry and thermoelectric power plants are the sources of $\mathrm{SO}_{4}{ }^{2-}$ and $\mathrm{NO}_{3}{ }^{-}[8,43]$. Nitrate and phosphate come from natural decomposition of rocks and minerals, atmospheric deposition, agricultural and industrial activities [58]. A strong correlation between $\mathrm{SO}_{4}{ }^{2-}$ and $\mathrm{NH}_{4}{ }^{+}(-0.56)$ indicates that the available $\mathrm{NH}_{3}$ in the atmosphere will principally react with $\mathrm{H}_{2} \mathrm{SO}_{4}$ to form $\left(\mathrm{NH}_{4}\right)_{2} \mathrm{SO}_{4}$ and $\mathrm{NH}_{4} \mathrm{HSO}_{4}$ referred by Seinfed [59].

\subsection{Principal component analysis (PCA)}

Principal Component Analysis (PCA) is a useful multivariate statistical method that used to identify the effect of probable sources of contaminants presents in rainwater samples [60-61]. In this study PCA was performed by using IBM SPSS Statistics 25. PCA of the rainwater quality parameters (Table 7) showed three PCs with eigenvalues greater than 1 explaining about $69 \%$ of the data variability. The parameters which were correlated significantly in correlation analysis also shows strong loading in PCA analysis. The three components were rotated using Varimax rotation procedure. A three-dimensional plot for all the variables in the component1, component2, and component3 is illustrated by Fig. 9. The first component (PC1) described $36 \%$ of the total variance and revealed strong loading among TDS (0.943), conductivity (0.930) and hardness (0.819), also moderate loading between $\mathrm{pH}(0.503)$ and turbidity $(0.730)$. This clustering of variables points to a common origin and these are in rainwater likely related to environmental conditions. 
Table 7

Varimax rotation for principal component analysis of selected parameters

\begin{tabular}{|lccc|}
\hline Variables & PC1 & PC2 & PC3 \\
\hline $\mathrm{pH}$ & .503 & -.196 & .422 \\
\hline TDS & .943 & .129 & -.087 \\
\hline Alkalinity & .930 & .193 & -.066 \\
\hline Hardness & .105 & -.100 & .773 \\
\hline Turbidity & .819 & .104 & .142 \\
\hline $\mathrm{NO}_{3}{ }^{-}$ & .730 & .126 & -.003 \\
\hline $\mathrm{SO}_{4}{ }^{2-}$ & .141 & .839 & .056 \\
\hline $\mathrm{PO}_{4}{ }^{3-}$ & .068 & .890 & -.025 \\
\hline $\mathrm{NH}_{4}{ }^{+}$ & .142 & .837 & -.081 \\
\hline Eigenvalue & -.108 & .098 & .658 \\
\hline$\%$ of Variance & 3.62 & 2.06 & 1.19 \\
\hline Cumulative Variance $(\%)^{-36}$ & 36 & 21 & 12 \\
\hline
\end{tabular}

The second component (PC2) consisting of nitrate $\left(\mathrm{NO}_{3}{ }^{-}\right)$, sulphate $\left(\mathrm{SO}_{4}{ }^{2-}\right)$ and phosphate $\left(\mathrm{PO}_{4}{ }^{3-}\right)$ accounted for approximately $21 \%$ of the total variance. PC2 revealed strong loading of $0.839,0.890$ and 0.837 of the photochemical species $\mathrm{NO}_{3}{ }^{-}, \mathrm{SO}_{4}{ }^{2-}$ and $\mathrm{PO}_{4}{ }^{3-}$, respectively. Anthropogenic activities are major sources of $\mathrm{NO}_{3}{ }^{-}$and $\mathrm{PO}_{4}{ }^{3-}$ pollution in rainwater as discussed earlier and same also reported by Fung and $\mathrm{Lau},(1998) . \mathrm{NO}_{3}{ }^{-}$and $\mathrm{SO}_{4}{ }^{2-}$ ions also define anthropogenic influences, such as incomplete fuel combustions, automobile exhaust, coal combustion, and industrial emissions discussed Xiao [32] and Zhang et al. [62].

The third and final component represented $12 \%$ of the total variance, having loadings of $0.422,0.773$ and 0.658 of $\mathrm{pH}$, alkalinity and $\mathrm{NH}_{4}{ }^{+}$, respectively. The existence of $\mathrm{NH}_{4}{ }^{+}$in the atmosphere may attribute to the utilization of fertilizers, volatilization of animal waste, human excreta, cattle farming, and also emitted from burning of fossil fuels [63-64]. The theoretical response shows that for oxidizing one milligram of ammonia, around $7.14 \mathrm{mg}$ of alkalinity (as CaCO3) is extracted [65]. As noted by Colt et al. [66], insufficient alkalinity could lead to incomplete nitrification and lower $\mathrm{pH}$ values in the sites. 


\section{Conclusions}

Detailed measurements have been undertaken to investigate the rainwater quality across different locations in the South-eastern region of Bangladesh. Based on this study, the following conclusions were made -

- The mean concentration of all tested physicochemical parameters, ions and trace metals in rainwater was found significantly lower compared to the drinking water quality standard of Bangladesh.

- The concentration of nitrate $\left(\mathrm{NO}_{3}{ }^{-}\right)$was found much lower in the investigated area in comparison to those observed in other sampling sites in the world. For the sampled locations, the mean concentration of nitrate $\left(\mathrm{NO}_{3}{ }^{-}\right)$and sulphate $\left(\mathrm{SO}_{4}{ }^{2-}\right)$ was recorded highest in the commercial area.

The observed values of $\mathrm{NH}_{4}{ }^{+}$within this study were much lower in precipitation compared to those observed in the sampling sites around the world.

- The trace metal concentrations ( $\mathrm{Fe}, \mathrm{Cu}, \mathrm{Zn}, \mathrm{Pb}, \mathrm{Mn}, \mathrm{Cr}$, and $\mathrm{Cd}$ ) of our study area were overall somewhat higher than those reported worldwide. Higher enrichment factor of metals suggesting the presence of anthropogenic sources. The mean concentration of trace metals in rainwater was followed a decreasing order: $\mathrm{Zn} \otimes \mathrm{Cu} \otimes \mathrm{Fe} \otimes \mathrm{Cr} \otimes \mathrm{Mn} \otimes \mathrm{Pb} \otimes \mathrm{Cd}$ in almost every sampling location.

- Trace metals concentration, especially copper $(\mathrm{Cu})$ and zinc $(\mathrm{Zn})$ were found maximum in the industrial area. The mean concentration of copper $(\mathrm{Cu})$ in industrial area was $74.7 \%, 48.2 \%$ and $35.6 \%$ greater than the commercial area, residential (urban) and residential (sub-urban) area, respectively.

- Principal component analysis was performed to find possible sources of the major species in rainwater. The parameters which were correlated significantly in correlation analysis also shows reliable loading in PCA analysis. The results showed that incomplete fuel combustions, industrial emissions, agricultural activities, and also environmental conditions were the dominant sources of the chemical composition in rainwater of Chattogram region.

Prior to this experimental investigations, limited knowledge was available in the chemical composition of rainwater in the southern-eastern region of Bangladesh, which has been attributed in this paper. Consequently, the data and findings of this extensive laboratory study would be useful to the engineers and researchers working in the sustainable use of water resources in Bangladesh, but particularly in southern-eastern region of the country.

\section{Declarations}

\section{Availability of data and materials}

Data will be available from the corresponding author on request.

\section{Competing interests}


The authors declare they have no competing interests.

\section{Funding}

This work was financially supported by a research grant sponsored by the WaterAid Bangladesh.

\section{Authors' contributions}

MAH and $\mathrm{AH}$ designed the study and performed the experiments. MGM and HJ fabricated the rainwater sample collection and conceived the original idea. MAH and MS wrote the first draft of the manuscript with the input from SKP. AH supervised the project. All authors read and approved the final manuscript.

\section{Acknowledgements}

The financial support of Water Aid Bangladesh is gratefully acknowledged. Authors would like to thank Mr Dawood Karim, Royal Cement Limited for his support in collecting the rainwater samples from Kumira location. Authors are also grateful to the Center for Environmental Science and Engineering Research and Department of Civil Engineering of the Chittagong University of Engineering \& Technology (CUET) for the technical supports in the laboratory work.

\section{References}

1. Al-Khashman OA. Chemical characteristics of rainwater collected at a western site of Jordan. Atmos Res. 2009;91(1):53-61.

2. Bertrand G, Celle-Jeanton H, Laj P, Rangognio J, Chazot G. Rainfall chemistry: long range transport versus below cloud scavenging. A two-year study at an inland station (Opme, France). J Atmos Chem. 2008;60(3):253-71.

3. Mohanakumar K. Stratospheric Influence on Tropospheric Weather and Climate. Stratosphere Troposphere Interactions: An Introduction. 2008;357 - 99.

4. Mix HT, Reilly SP, Martin A, Cornwell G. Evaluating the Roles of Rainout and Post-Condensation Processes in a Landfalling Atmospheric River with Stable Isotopes in Precipitation and Water Vapor. Atmosphere. 2019;10(2):86.

5. Wang H, Han G. Chemical composition of rainwater and anthropogenic influences in Chengdu, Southwest China. Atmos Res. 2011;99(2):190-6.

6. Kulshrestha UC, Kulshrestha MJ, Sekar R, Sastry GS, Vairamani M. Chemical characteristics of rainwater at an urban site of south-central India. Atmos Environ. 2003;37(21):3019-26.

7. Wu Q, Han G, Tao F, Tang Y. Chemical composition of rainwater in a karstic agricultural area, Southwest China: the impact of urbanization. Atmos Res. 2012;111:71-8.

8. Salve PR, Maurya A, Wate SR, Devotta S. Chemical composition of major ions in rainwater. Bull Environ Contam Toxicol. 2008; 80(3):242-6. 
9. Tiwari S, Srivastava MK, Bisht DS. Chemical composition of rainwater in Panipat, an industrial city in Haryana. Indian J Radio Space Phys. 2008; 37, 443-449.

10. Brammer H. Bangladesh's dynamic coastal regions and sea-level rise. Clim Risk Manage. 2014; $1: 51-62$.

11. Akter A, Ali MH. Arsenic contamination in groundwater and its proposed remedial measures. Int $\mathrm{J}$ Environ Sci Technol. 2011;8(2):433-43.

12. Jabed MA, Paul A, Nath TK. Peoples' perception of the water salinity impacts on human health: A case study in South-Eastern Coastal Region of Bangladesh. Exposure and Health. 2020;12(1):41-50.

13. Ahmed MJ, Ahsan A, Haque MR, Siraj S, Bhuiyan MH, Bhattacharjee SC, Islam S. Physicochemical assessment of surface and groundwater quality of the greater Chittagong region of Bangladesh. Pak J Anal Environ Chem. 2010;11(2):11.

14. Hossen MA, Jishan RA. Water quality assessment in terms of water quality index: a case study of the Halda River, Chittagong. Appl J Environ Eng Sci. 2018;4(4):4.

15. Akter A, Ahmed S. Potentiality of rainwater harvesting for an urban community in Bangladesh. J Hydrol. 2015;528:84-93.

16. Alam R, Munna G, Chowdhury MA, Sarkar MS, Ahmed M, Rahman MT, Jesmin F, Toimoor MA. Feasibility study of rainwater harvesting system in Sylhet City. Environ Monit Assess. 2012;184(1):573-80.

17. Bashar MZ, Karim MR, Imteaz MA. Reliability and economic analysis of urban rainwater harvesting: A comparative study within six major cities of Bangladesh. Resour Conserv Recycl. 2018;133:14654.

18. Mia MA, Nasrin S, Zhang M, Rasiah R. Chittagong, Bangladesh. Cities. 2015;48:31-41.

19. BBS. Statistical yearbook of Bangladesh. Statistics Division, Ministry of Planning, Dhaka, Government of the People's Republic of Bangladesh. 2011.

20. BBS. Statistical yearbook of Bangladesh. Statistics Division, Ministry of Planning, Dhaka, Government of the People's Republic of Bangladesh. 2013.

21. Roy S, Pandit S, Eva EA, Bagmar MS, Papia M, Banik L, Dube T, Rahman F, Razi MA. Examining the nexus between land surface temperature and urban growth in Chattogram Metropolitan Area of Bangladesh using long term Landsat series data. Urban Clim. 2020;32:100593.

22. BMD. Bangladesh Metrological Department, Annual Rainfall and Temperature Analysis. 2013. http://www.bmd.gov.bd/ (accessed 19th March 2019).

23. Uddin N. Assessing urban sustainability of slum settlements in Bangladesh: Evidence from Chittagong city. J Urban Manage. 2018;7(1):32-42.

24. Shamsher R, Abdullah MN. Traffic congestion in Bangladesh-causes and solutions: a study of Chittagong metropolitan city. Asian Bus Rev. 2013;2(1):13-8.

25. Masum MH, Pal SK. Statistical evaluation of selected air quality parameters influenced by COVID-19 lockdown. Global J Environ Sci Manage. 2020;6(Special Issue (Covid-19)):85-94. 
26. Abdullah HM, Mahboob MG, Banu MR, Seker DZ. Monitoring the drastic growth of ship breaking yards in Sitakunda: a threat to the coastal environment of Bangladesh. Environ Monit Assess. 2013;185(5):3839-51.

27. Hasan AB, Kabir S, Reza AS, Zaman MN, Ahsan MA, Akbor MA, Rashid MM. Trace metals pollution in seawater and groundwater in the ship breaking area of Sitakund Upazilla, Chittagong, Bangladesh. Mar Pollut Bull. 2013;71(1-2):317-24.

28. Hossain MS, Fakhruddin AN, Chowdhury MA, Gan SH. Impact of ship-breaking activities on the coastal environment of Bangladesh and a management system for its sustainability. Environ Sci Policy. 2016;60:84-94.

29. Gikas GD, Tsihrintzis VA. Assessment of water quality of first-flush roof runoff and harvested rainwater. J Hydrol. 2012;466:115-26.

30. Kus B, Kandasamy J, Vigneswaran S, Shon HK. Analysis of first flush to improve the water quality in rainwater tanks. Water Sci Technol. 2010;61(2):421-8.

31. Zhu K, Zhang L, Hart W, Liu M, Chen H. Quality issues in harvested rainwater in arid and semi-arid Loess Plateau of northern China. J Arid Environ. 2004;57(4):487-505.

32. Xiao J. Chemical composition and source identification of rainwater constituents at an urban site in Xi'an. Environ. Earth Sci. 2016;75(3):209.

33. Zhao M, Li L, Liu Z, Chen B, Huang J, Cai J, Deng S. Chemical composition and sources of rainwater collected at a semi-rural site in Ya'an, Southwestern China. Atmos Clim Sci. 2013;2013.

34. Li XY, Xie ZK, Yan XK. Runoff characteristics of artificial catchment materials for rainwater harvesting in the semiarid regions of China. Agric. Water Manage. 2004;65(3):211-24.

35. Despins C, Farahbakhsh K, Leidl C. Assessment of rainwater quality from rainwater harvesting systems in Ontario, Canada. J Water Supply Res Technol AQUA. 2009;58(2):117-34.

36. Huston R, Chan YC, Chapman H, Gardner T, Shaw G. Source apportionment of heavy metals and ionic contaminants in rainwater tanks in a subtropical urban area in Australia. Water Res. 2012;46(4):1121-32.

37. Joshi UM, Balasubramanian R. Characteristics and environmental mobility of trace elements in urban runoff. Chemosphere. 2010;80(3):310-8.

38. Wong CS, Li X, Thornton I. Urban environmental geochemistry of trace metals. Environ Pollut. 2006;142(1):1-6.

39. Gunawardena J, Egodawatta P, Ayoko GA, Goonetilleke A. Atmospheric deposition as a source of heavy metals in urban stormwater. Atmos Environ. 2013;68:235-42.

40. Bharti PK, Singh V, Tyagi PK. Assessment of rainwater quality in industrial area of rural Panipat (Haryana), India Arch Agric Environ Sci. 2017;2(3):219-23.

41. Wu L, Gao J, Zhao W, Xu X, Yin Y, Wu L. Quality assessment of rainwater and harvested rainwater stored in different types of cisterns. Water Sci Technol Water Supply. 2017;17(3):652-64. 
42. Moon SH, Lee JY, Lee BJ, Park KH, Jo YJ. Quality of harvested rainwater in artificial recharge site on Jeju volcanic island, Korea. J Hydrol. 2012;414:268-77.

43. Báez A, Belmont R, García R, Padilla H, Torres MD. Chemical composition of rainwater collected at a southwest site of Mexico City, Mexico. Atmos Res. 2007;86(1):61-75.

44. Singh KP, Singh VK, Malik A, Sharma N, Murthy RC, Kumar R. Hydrochemistry of wet atmospheric precipitation over an urban area in Northern Indo-Gangetic Plains. Environ Monit Assess. 2007; $131(1-3): 237$.

45. Li Y, Wang Y, Ding A, Liu X, Guo J, Li P, Sun M, Ge F, Wang W. Impact of long-range transport and under-cloud scavenging on precipitation chemistry in East China. Environ Sci Pollut Res. 2011;18(9):1544.

46. Hou H, Takamatsu T, Koshikawa MK, Hosomi M. Trace metals in bulk precipitation and throughfall in a suburban area of Japan. Atmos Environ. 2005;39(20):3583-95.

47. Wang H, Han G. Chemical composition of rainwater and anthropogenic influences in Chengdu, Southwest China. Atmos Res. 2011;99(2):190-6.

48. Cerqueira MR, Pinto MF, Derossi IN, Esteves WT, Santos MD, Matos MA, Lowinsohn D, Matos RC. Chemical characteristics of rainwater at a southeastern site of Brazil. Atmos Pollut Res. 2014;5(2):253-61.

49. Kaya G, Tuncel G. Trace element and major ion composition of wet and dry depositon in Ankara, Turkey. Atmos Environ. 1997;31(23):3985-98.

50. Hirose K, Labrosse S, Hernlund J. Composition and state of the core. Annu Rev Earth Planet Sci. 2013;41:657-91.

51. Rudnick RL, Gao S. Composition of the continental crust. The crust. 2003;3:1-64.

52. Cao YZ, Wang S, Zhang G, Luo J, Lu S. Chemical characteristics of wet precipitation at an urban site of Guangzhou, South China. Atmos Res. 2009;94(3):462-9.

53. Xing J, Song J, Yuan H, Li X, Li N, Duan L, Qu B, Wang Q, Kang X. Chemical characteristics, deposition fluxes and source apportionment of precipitation components in the Jiaozhou Bay, North China. Atmos Res. 2017;190:10-20.

54. Uygur N, Karaca F, Alagha O. Prediction of sources of metal pollution in rainwater in Istanbul, Turkey using factor analysis and long-range transport models. Atmos Res. 2010;95(1):55-64.

55. Gioda A, Mayol-Bracero OL, Scatena FN, Weathers KC, Mateus VL, McDowell WH. Chemical constituents in clouds and rainwater in the Puerto Rican rainforest: potential sources and seasonal drivers. Atmos Environ. 2013;68:208-20.

56. Fenn ME, Ross CS, Schilling SL, Baccus WD, Larrabee MA, Lofgren RA. Atmospheric deposition of nitrogen and sulfur and preferential canopy consumption of nitrate in forests of the Pacific Northwest, USA. For Ecol Manage. 2013;302:240-53.

57. Hoseinzadeh E, Wei C, Safari M, Godini H. Evaluation of rainwater quality using factor analysis: case study of Khorramabad in western Iran. Desalin Water Treat. 2016;57(53):25345-57. 
58. da Conceição FT, Antunes ML, Angelucci VA, Moruzzi RB, Navarro GR. Rainwater chemical composition and annual atmospheric deposition in sorocaba (São Paulo State), Brazil. Braz J Geophys. 2013;31(1):5-15.

59. Seinfeld JH, Pandis SN. Atmospheric chemistry and physics: from air pollution to climate change. John Wiley \& Sons. 2016.

60. Machiwal D, Jha MK. Identifying sources of groundwater contamination in a hard-rock aquifer system using multivariate statistical analyses and GIS-based geostatistical modeling techniques. J Hydrol: Reg Stud. 2015;4:80-110.

61. Palma P, Alvarenga P, Palma VL, Fernandes RM, Soares AM, Barbosa IR. Assessment of anthropogenic sources of water pollution using multivariate statistical techniques: a case study of the Alqueva's reservoir, Portugal. Environ Monit Assess. 2010;165(1-4):539-52.

62. Zhang M, Wang S, Wu F, Yuan X, Zhang Y. Chemical compositions of wet precipitation and anthropogenic influences at a developing urban site in southeastern China. Atmos Res. 2007;84(4):311-22.

63. Migliavacca DM, Teixeira EC, Rodriguez MT. Chemical composition of wet precipitation at Metropolitan Porto Alegre, Brazil, 2005-2007. Quim Nova. 2012;35(6):1075-83.

64. Bouwman AF, Boumans LJ, Batjes NH. Estimation of global NH3 volatilization loss from synthetic fertilizers and animal manure applied to arable lands and grasslands. Global Biogeochem Cycles. 2002;16(2):8-1.

65. Chen S, Ling J, Blancheton JP. Nitrification kinetics of biofilm as affected by water quality factors. Aquacult Eng. 2006;34(3):179-97.

66. Colt J, Watten B, Rust M. Modeling carbon dioxide, $\mathrm{pH}$, and un-ionized ammonia relationships in serial reuse systems. Aquacult Eng. 2009;40(1):28-44.

\section{Figures}




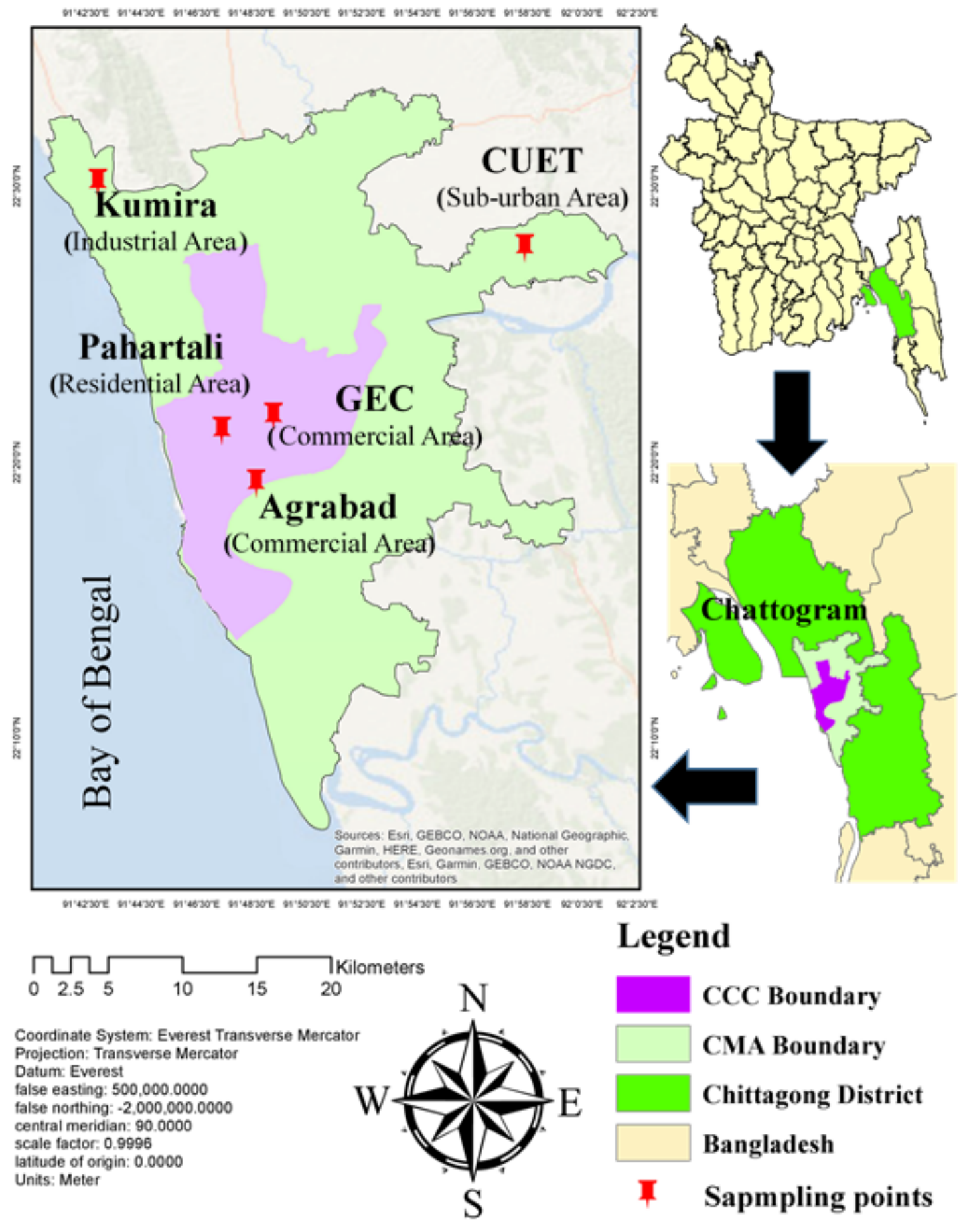

\section{Figure 1}

Study area map indicating sampling locations Note: The designations employed and the presentation of the material on this map do not imply the expression of any opinion whatsoever on the part of Research Square concerning the legal status of any country, territory, city or area or of its authorities, or concerning the delimitation of its frontiers or boundaries. This map has been provided by the authors. 


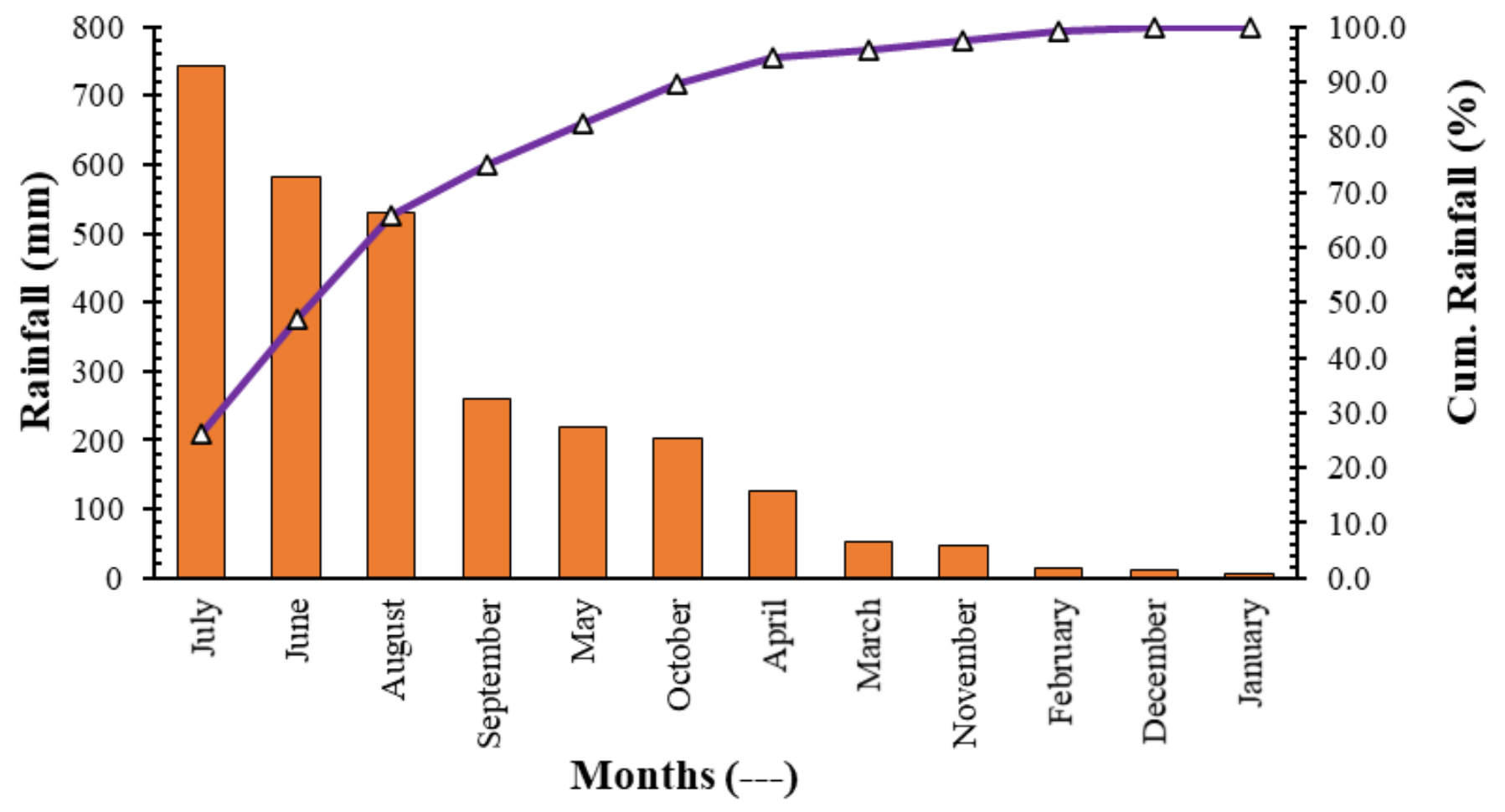

Figure 2

The monthly average rainfall scenario in the study area during the period (1982 - 2017) 


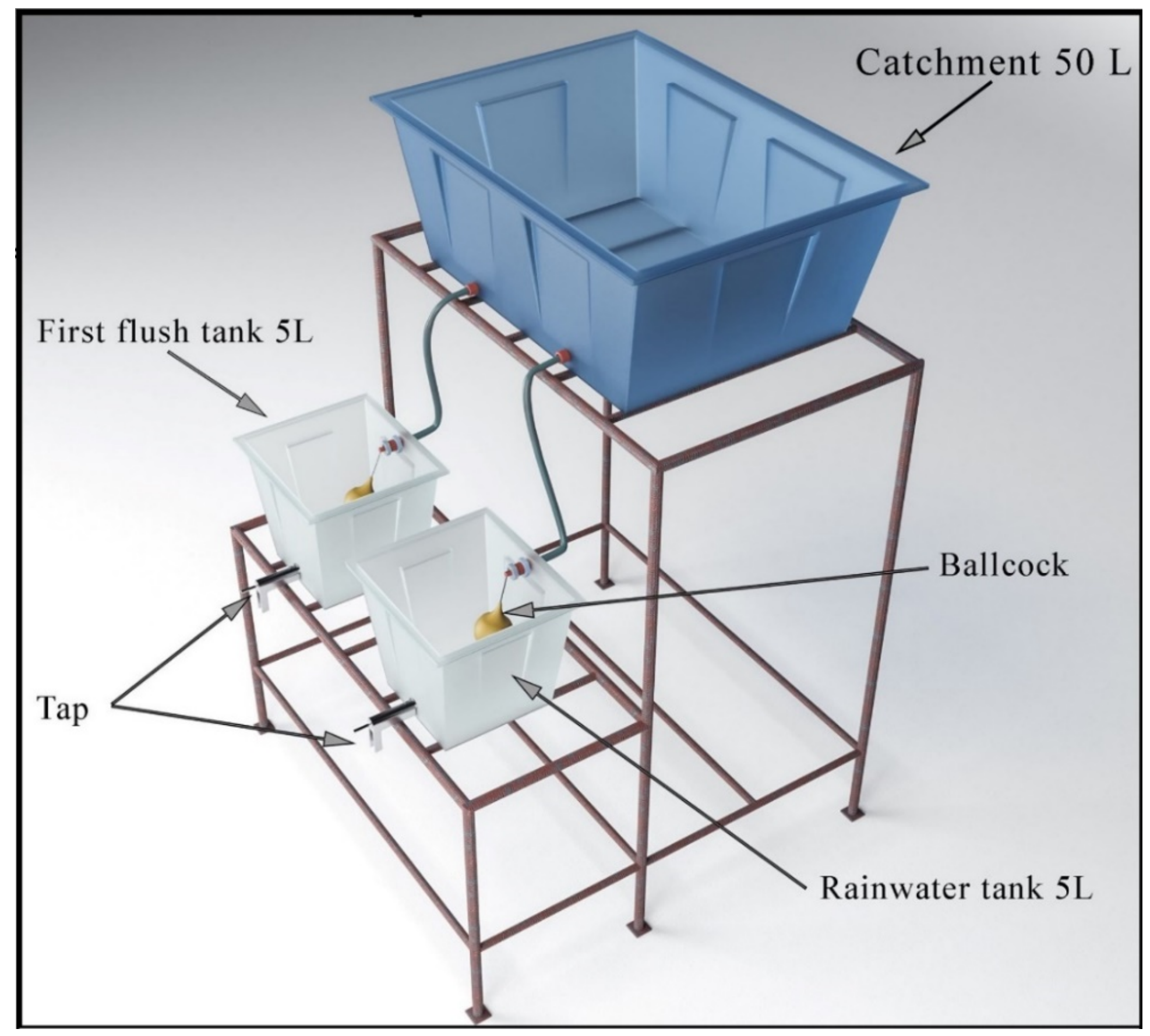

Figure 3

Schematic diagram of rainwater sample collection designed and used in this study 


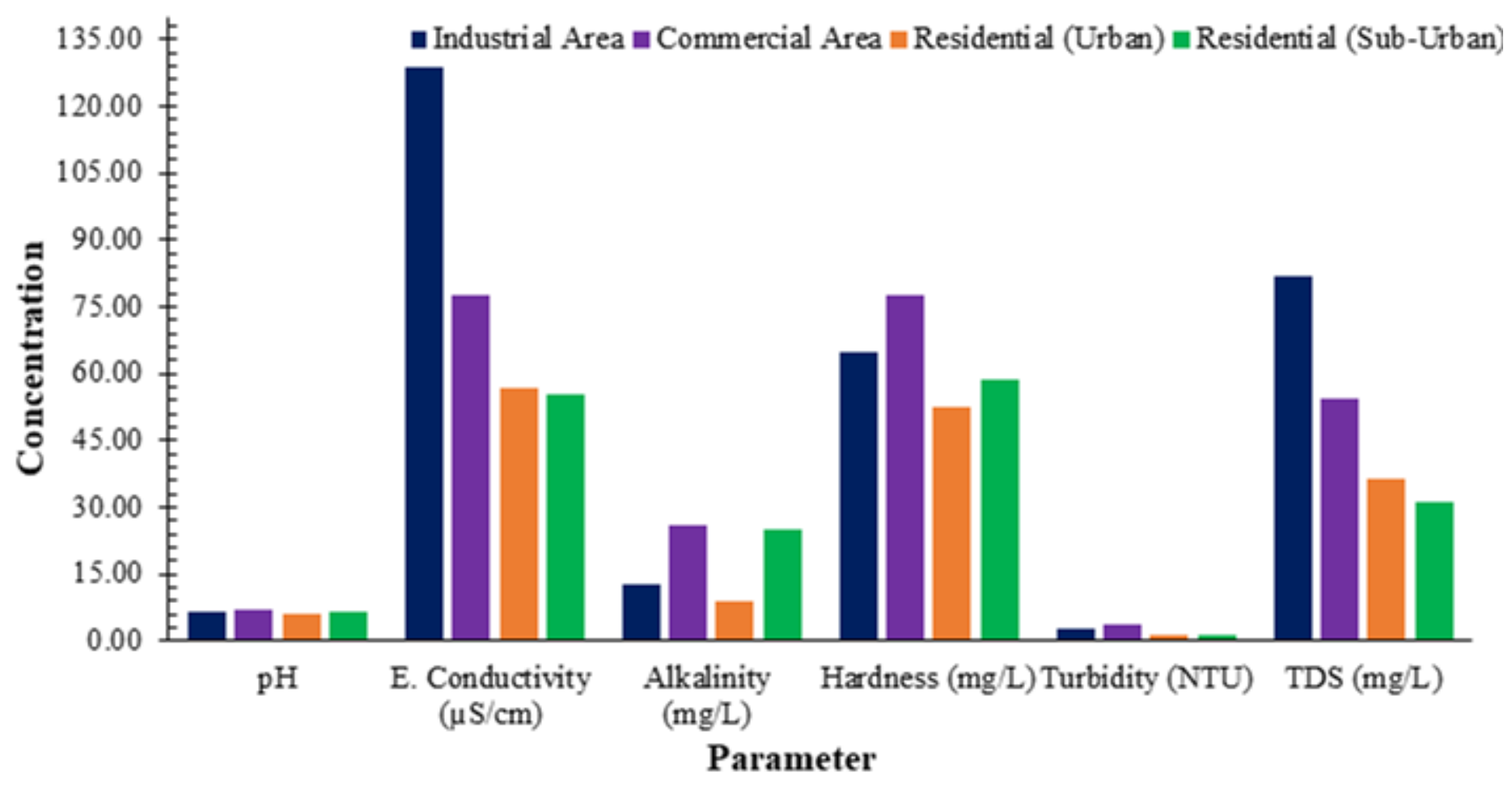

Figure 4

Average value of physicochemical parameters

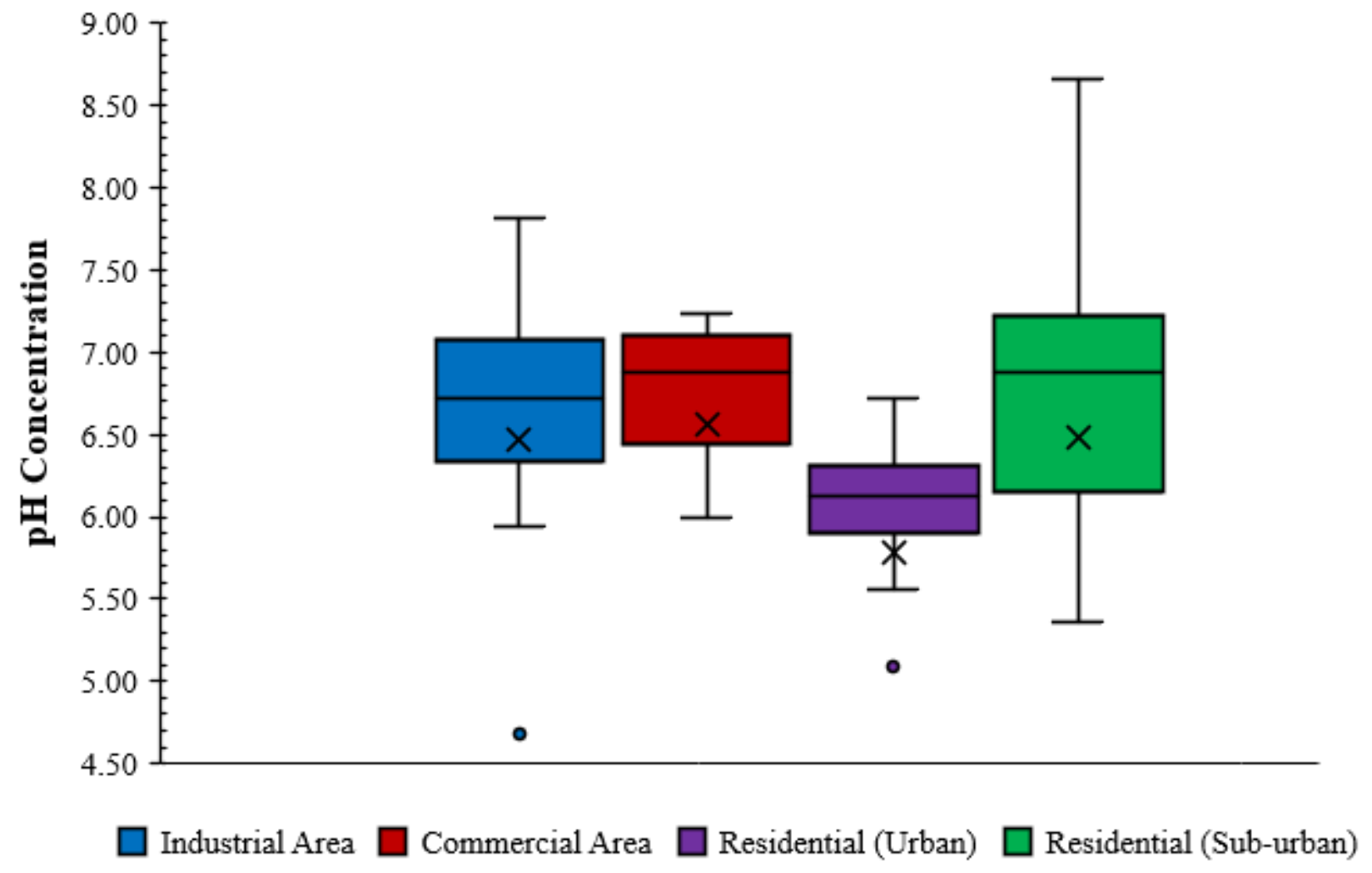

Figure 5 
Box plot diagram of $\mathrm{pH}$ in rainwater at different locations

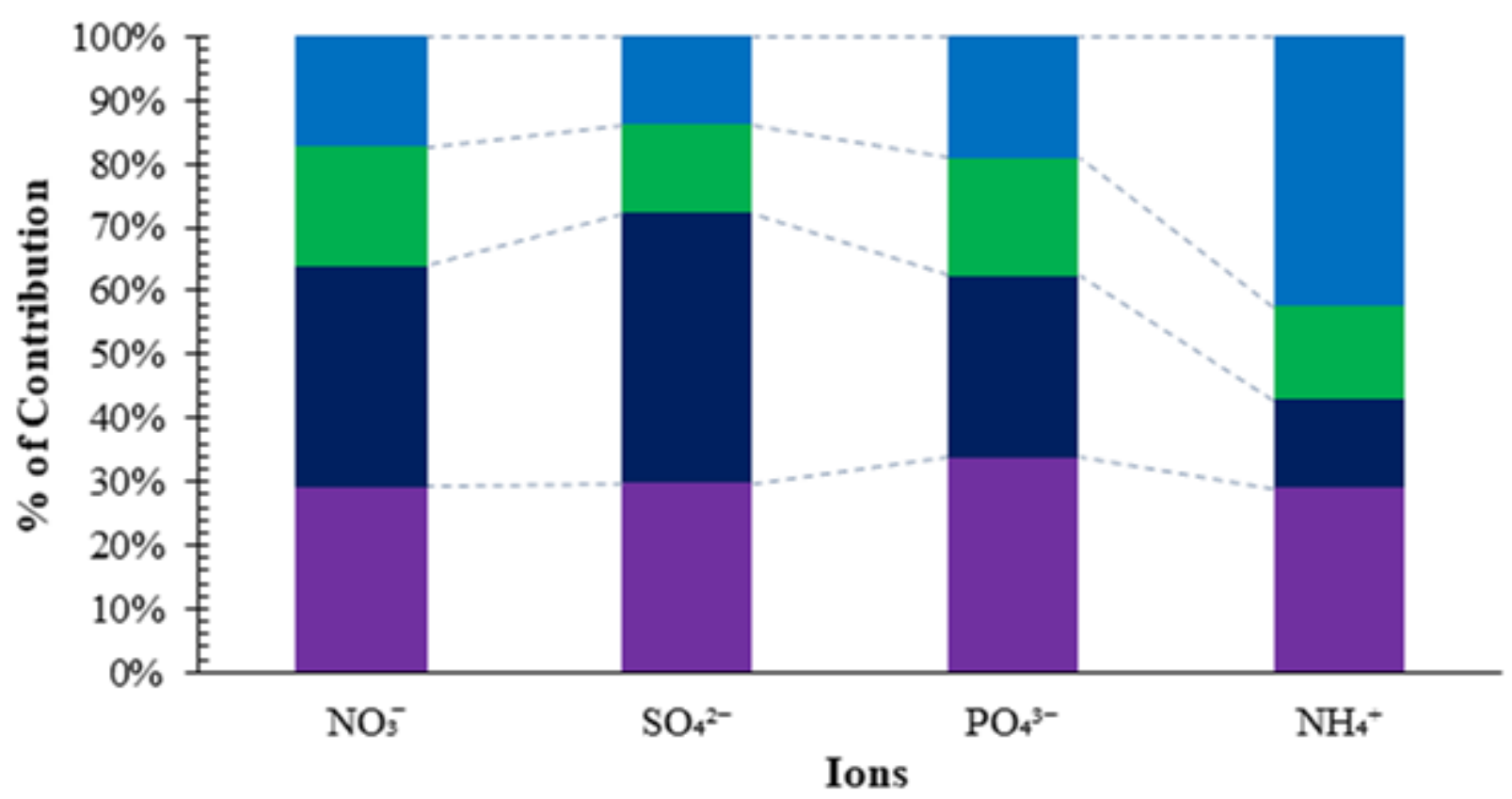

घIndustrial Area $\quad$ Commercial Area $\|$ Residential (Urban) $\|$ Residential (Sub-Urban)

\section{Figure 6}

Frequency distribution of major ions in rainwater
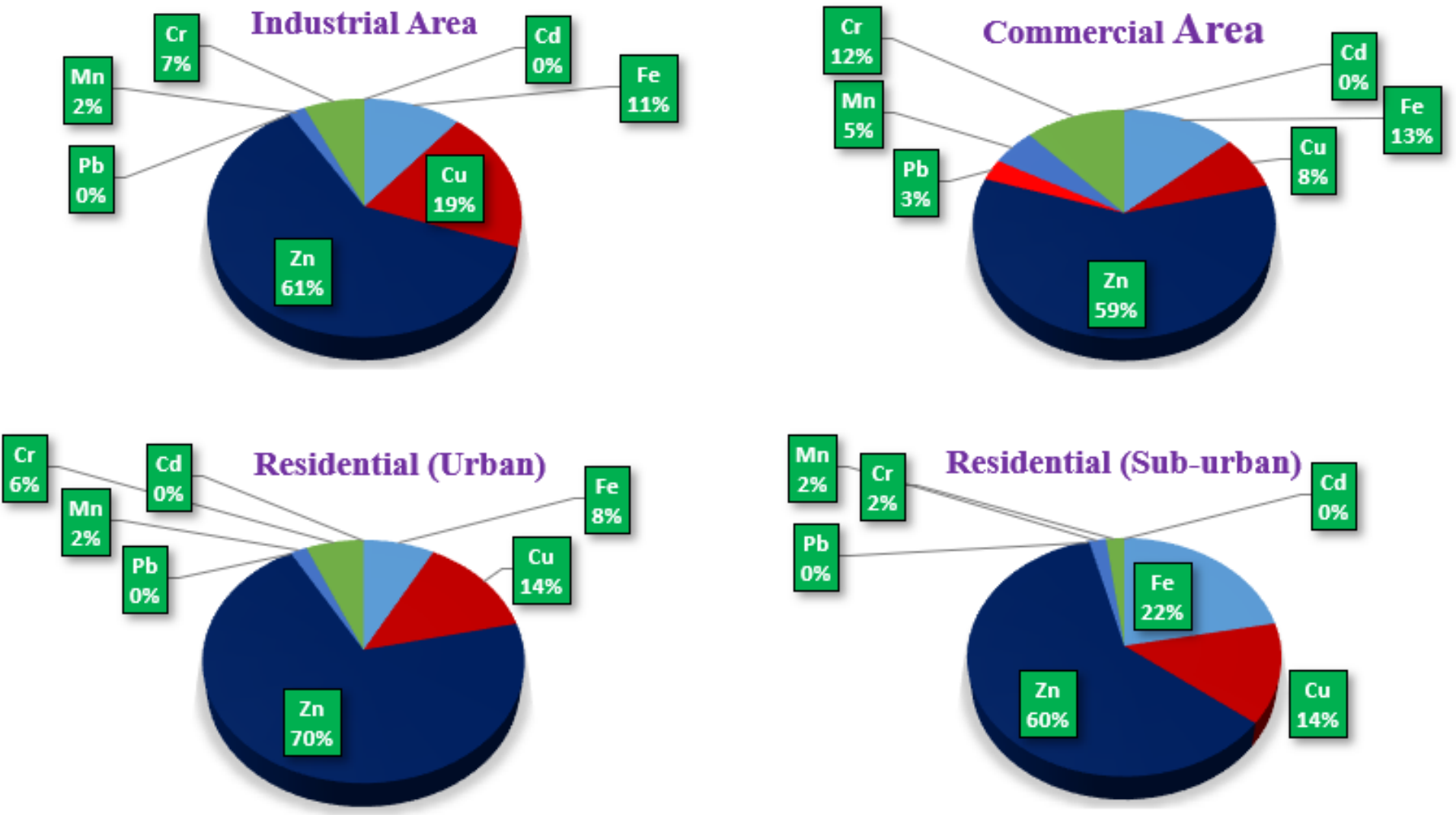

Figure 7 
The contribution of metals in rainwater at different land use locations

$e^{\lambda} \quad p^{s}<0$

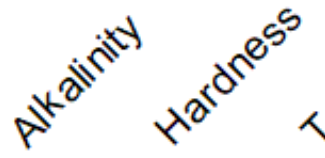<smiles>[CH][CH]</smiles><smiles>[C+][CH]</smiles><smiles>O=C=O</smiles>

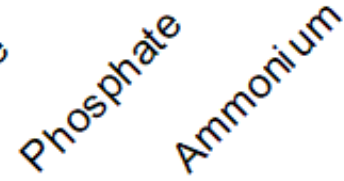

$\mathrm{pH}$

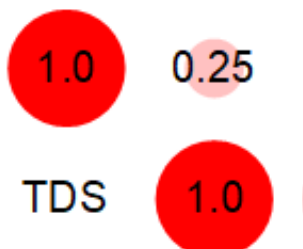

$\begin{array}{llll}0.22 & -0.039 & 0.0018 & 0.16\end{array}$

$-0.33$

$-0.57$

$-0.57-0.23$

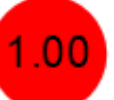

$-0.035$

0.70

$0.54-0.076$

0.15

$-0.021$

$-0.58$

EC

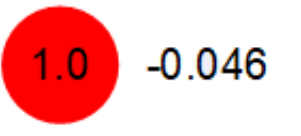

$0.70 \quad 0.52-0.050$

0.19

0.023

$-0.60$

Alkalinity 1.0

0.55

$0.37 \quad-0.30$

$0.29 \quad-0.47$

$-0.12$

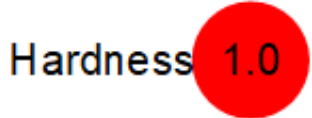

$\begin{array}{llll}0.54 & -0.23 & 0.47 & -0.12\end{array}$

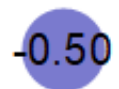

Turbidity

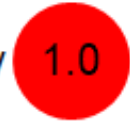

0.30

0.35

0.014

$-0.71$

Nitrate

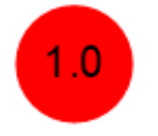

0.48

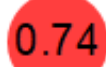

$-0.42$

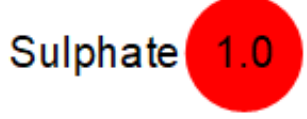

0.68
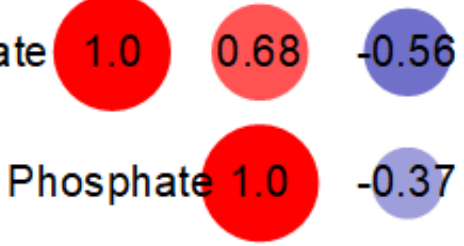

$-0.37$
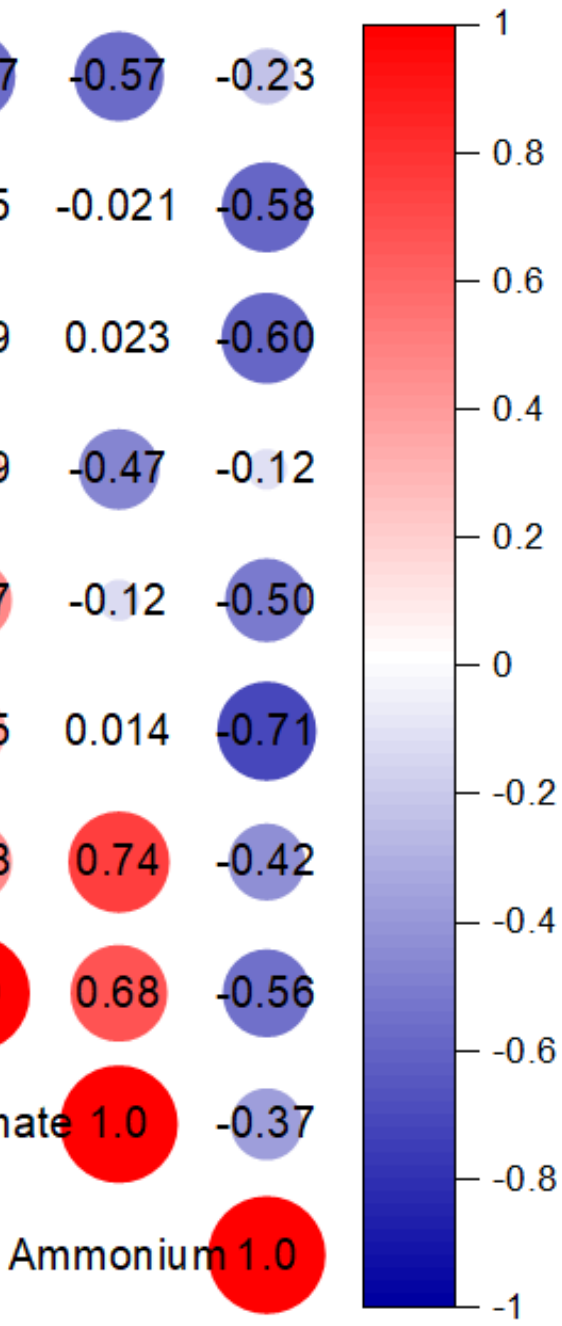

Figure 8

Correlation matrix among selected rainwater quality parameters 


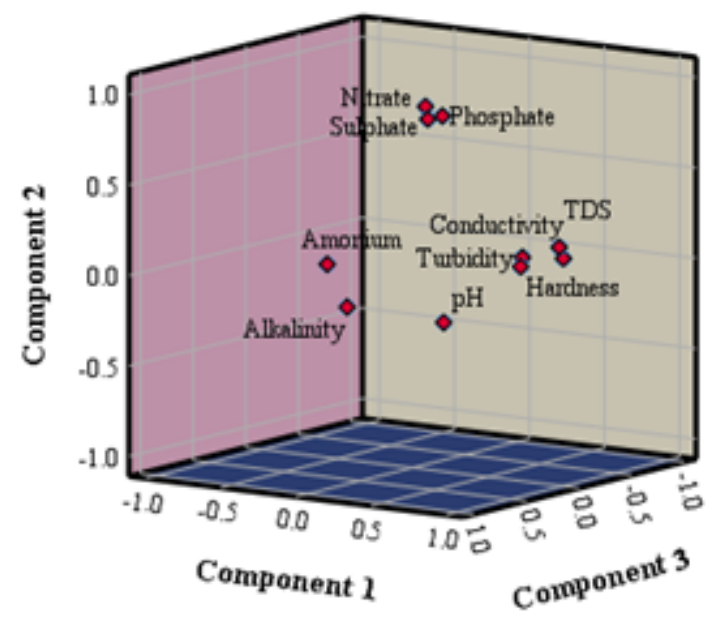

Figure 9

Component plot of different factors 